\title{
ESR1 Gene Mutation
}

National Cancer Institute

\section{Source}

National Cancer Institute. ESR1 Gene Mutation. NCI Thesaurus. Code C136629.

A change in the nucleotide sequence of the ESR1 gene. 